\title{
ASSESSMENT OF VARIOUS SURFACE AREASS OF STUDENT'S REST ROOMS FOR PATHOGENIC MICROBIAL FLORA IN TERTIARY CARE HOSPITAL OF CENTRAL INDIA
}

\author{
Dr. Vinod Kumar \\ Rai
}

Mr. C. Munisankar Reddy*

\author{
Assistant Professor, Department of Microbiology, L.N. Medical College \& \\ Research Centre, Bhopal, Madhya Pradesh.
}

\section{ABSTRACT}

Assistant Professor, Department of Microbiology, L.N. Medical College \& Research Centre, Bhopal, Madhya Pradesh. *Corresponding Author \begin{abstract}
The purpose of this study was screening of various surface areas of Student's restrooms for pathogenic microbial flora in Hospital settings. Aim\& Result: This Prospective Analytical study was conducted in the Department of Microbiology, attached to a Tertiary Care Hospital over a period of three months. One hundred forty-four out of 150 samples were culture positive from various surface areas of students' restrooms. Out of 144 isolates, Gram negative bacilli $(n=46)$ were more common than Gram positive cocci $(n=38)$. Ampicillin is more resistant in Gram positive cocci. Conclusion: Present study highlights the need of sensitization \& training sessions regarding hand hygiene practices among the student's and regular cleaning of inanimate objects like Toilets for reduction of infectious microbial diseases.
\end{abstract}

KEYWORDS : Sanitization, antibiocribial sensitivity, surface contamination, microbial flora

\section{INTRODUCTION:}

It is essential to carry out antibiotic susceptibility testing because it guides clinicians in selecting an appropriate treatment regimen for an infection. Bacteria are ubiquitous and constitute an important part of every ecosystem, few causing disease are called pathogenic bacteria may also lead to death of affected individual. Public restrooms may contain a variety of dangerous bacteria like Escherichia, Salmonella, Methicillin-resistant Staphylococcus aureus (MRSA) and Streptococcus spp.[1-4] Even after multiple flushing and cleaning with disinfectants, bacteria seed into toilets and survive there for a long time. Majority, including Shigella species, Escherichia species, Clostridium species, can survive on surfaces for weeks to months.[5] Restrooms get contaminate with microbes from human source such as saliva, skin, urine, and feces and get dispersed through improperly washed hands to flushing handles, door handles, faucets of toilets and other equipment.[6] The inefficient cleanliness of toilets and shortage of water as well predispose students to urinary tract Infections (UTI), boil and diseases such as food borne diseases.[7] The first line defense in preventing the spread of disease is by hand washing that is ignored and must be emphasized strongly by families, schools, hostels and health care professionals. [8] On the other hand, many people wash their hands only with water without using detergents and some fail to wash their hands after using the public toilets.[5,9] The study is done for finding microbial flora on various surface of public restroom along with antibiogram of pathogenic bacteria from students' toilets that might get transmitted from one person to another causing community acquired infection. So, this study is emphasizing on need for maintenance of high level of hygiene on surface of fomites like toilet seats, flushes handles, rim and area between flushing rim and toilet bowl. Thus, information obtained from this study will help students to take hygienic precautions when using toilets and advice the management about importance of effective cleanliness.

\section{MATERIAL AND METHODS:}

This Prospective Analytical study was conducted in the Department of Microbiology, attached to a Tertiary Care Hospital in Central India. Over a time of two months from $1^{\text {st }}$ August to $30^{\text {th }}$ Sep 2020. A Total of 150 samples were taken from various surface areas of student's restrooms. From each toilet, three samples were collected that are: Toilet bowel, toilet flush handle \& door handle inside the restroom. Collection of Samples: Samples for this study were collected at a single point in time from the student's restroom. From each toilet, three samples were collected from various surfaces; surfaces associated with toilets (toilet bowl) and surfaces routinely touched with hands (door handles inside the restroom and toilet flush handles) using sterile cotton swab moistened with sterile Trypticase soy broth (TSB) (Himedia, ILA). Each swab kept into a separate tube containing $10 \mathrm{ml}$ of sterile Trypticase soy broth (TSB) (Himedia, ILA). The tube was labeled to indicate date of collection, hostel, toilet, and the type of surface where the samples were collected. Then samples were transported immediately to Microbiology Laboratory at Tertiary care hospital. After receiving the sample in the lab, samples were incubated over night to dislodge the microorganisms into the medium which were inoculated on Blood agar and MacConkey agar (Hi Media Pvt. Ltd, Mumbai, India) \& incubated at $37^{\circ} \mathrm{C}$ for 18-24 hours \& prepare direct smear from cotton swab and Gram staining for primary identification of isolates was done. After 24 hours of incubation, the colonies were examined under magnifying lens and identified using the standard microbiological procedures like colony morphology, motility, Gram staining and biochemical reactions as described in Practical Microbiology of the Mackie \& Mac Cartney $14^{\text {th }}$ volume.[10]

\section{RESULT \& OBSERVATION:}

A Total of 150 samples were taken from various surface areas of students' restrooms. From each toilet, three samples were collected that are: Toilet bowel, toilet flush handle \& door handle inside the restroom. Out of 150 samples, 144 (96\%) samples were culture positive. The distribution of culture positive samples from various surface areas of student's restroom is shown in table l. Maximum no. of culture positive samples was from TB (50) followed by TFH (49) than DH (45). Total isolated organisms were 144. Out of 144 isolates, Gram negative bacilli $(n=62)$ were less common than Gram positive cocci $(n=82)$. Number and percentage of isolated bacteria from various surface areas of student's restroom are shown in Table 2. The interpretation of results was based on the Standards for antimicrobial susceptibility Testing established by the Clinical and Laboratory Standards Institute (CLSI, 2016). Antibiotic resistance pattern of all isolates is shown in Table 3.

\section{Table 1}

Culture positive samples and isolated bacteria from various surface areas of student's restrooms

\begin{tabular}{|c|c|c|}
\hline Site of sample collection & \begin{tabular}{|l|} 
No. of \\
sample \\
collected
\end{tabular} & \begin{tabular}{|l|}
$\begin{array}{l}\text { Culture positive } \\
\text { samples }\end{array}$ \\
GPC|GNB
\end{tabular} \\
\hline
\end{tabular}




\begin{tabular}{|l|l|l|l|l|}
\hline Toilet bowel (TB) & 50 & 12 & 38 & 50 \\
\hline Toilet flush handle (TFH) & 50 & 36 & 13 & 49 \\
\hline Door handle inside restroom (DH) & 50 & 34 & 11 & 45 \\
\hline Total & 150 & 144 \\
\hline
\end{tabular}

Table 2

Number and percentage of isolated bacteria from various surface areas of student's restrooms

\begin{tabular}{|c|c|c|}
\hline Isolated organism & No. of isolated bacteria & Percentage \\
\hline \multicolumn{3}{|c|}{ Gram Positive } \\
\hline
\end{tabular}

\begin{tabular}{|l|l|l|}
\hline Staphylococcus aureus & 48 & $33.33 \%$ \\
\hline Streptococcus pyogenes & 34 & $23.61 \%$ \\
\hline Subtotal & 82 & \\
\hline \multicolumn{2}{|c|}{ Gram Negative } \\
\hline Citrobacter spp. & 23 & $15.97 \%$ \\
\hline Pseudomonas aeruginosa & 12 & $8.33 \%$ \\
\hline Klebsiella pneumonia & 10 & $6.94 \%$ \\
\hline Salmonella typhi & 11 & $7.63 \%$ \\
\hline Shigella spp. & 6 & $4.16 \%$ \\
\hline Subtotal & 62 & \\
\hline Total isolate & 144 & \\
\hline
\end{tabular}

Table 3

\begin{tabular}{|c|c|c|c|c|c|c|c|c|c|}
\hline \multicolumn{10}{|c|}{ Antibiotic resistance patterns of isolated bacteria from various surface areas of student's restroom } \\
\hline $\begin{array}{l}\text { Bacterial } \\
\text { isolates }\end{array}$ & & $\begin{array}{c}\text { AMPICILLINE } \\
\%\end{array}$ & $\begin{array}{c}\text { ERYTHROMYCIN } \\
\%\end{array}$ & $\begin{array}{c}\text { CLINDAMYCIN } \\
\%\end{array}$ & $\begin{array}{c}\text { GENTAMICIN } \\
\%\end{array}$ & $\begin{array}{c}\text { COTRIMOXA } \\
\text { ZOLE \% }\end{array}$ & \begin{tabular}{|l|} 
CIPROFL \\
OXACIN\%
\end{tabular} & \begin{tabular}{|c|} 
CEFOXITI \\
ME\%
\end{tabular} & \begin{tabular}{|c|} 
CHLORA \\
MPHENIC \\
OL\% \\
\end{tabular} \\
\hline \multicolumn{10}{|l|}{$\begin{array}{c}\text { Gram } \\
\text { positive }\end{array}$} \\
\hline $\begin{array}{l}\text { Staph. } \\
\text { aureus }\end{array}$ & 48 & 25 & 12 & 46 & 19 & 17 & 13 & 16 & 6 \\
\hline $\begin{array}{c}\text { Strep. } \\
\text { pyrogens }\end{array}$ & 34 & 4 & 9 & 12 & 10 & 6 & 7 & 10 & 4 \\
\hline \multicolumn{10}{|l|}{$\begin{array}{c}\text { Gram } \\
\text { negative }\end{array}$} \\
\hline $\begin{array}{l}\text { Citrobactter } \\
\text { spp. }\end{array}$ & 23 & 4 & 23 & - & - & 6 & 7 & 3 & 8 \\
\hline $\begin{array}{c}\text { Pseudo. } \\
\text { Aeruginosa }\end{array}$ & 12 & 20 & 26 & 4 & 3 & 20 & 14 & 34 & 43 \\
\hline $\begin{array}{c}\text { Klebsiella } \\
\text { pneunomia }\end{array}$ & 10 & 80 & 34 & - & - & 12 & 17 & 20 & 21 \\
\hline $\begin{array}{l}\text { Shigella } \\
\text { spp. }\end{array}$ & 6 & 1 & 3 & - & - & 33 & 23 & 21 & 15 \\
\hline $\begin{array}{c}\text { Salmonella } \\
\text { typhi }\end{array}$ & 11 & 15 & 21 & - & 3 & 27 & 34 & 23 & 21 \\
\hline
\end{tabular}

\section{DISCUSSION:}

This prospective analytical study was conducted in Department of Microbiology in a Medical College attached to a Tertiary care hospital over a period of two months. The purpose of this study was to isolate, identify and screen various surface areas of student's restrooms for pathogenic microbial flora in central India. It has been reported that some students or even many people have a habit of not washing their hands or wash hands for short time with or without soap after using restroom. Thus, transmitting microorganisms from one area to another and from one individual to other. In the present study, Staphylococcus aureus is found to be more prevalent from student's restrooms and all were MRSA. Similar study by Agbagwa and Nwechem et al (2010) indicated S. aureus more prevalent in public toilets. [12] In contrast study done by Adewoyin et al (2013) indicated Streptococcus species (especially Str. faecium) to be more prevalent in the toilet-bowl of student's hostels. Both the above studies show higher prevalence of Staphylococcus aureus which is a leading cause of nosocomial infection. In our study, we have observed that the frequency of bacterial isolates were higher in the TB followed by TFH and DH inside the restroom and demonstrates that majority of the bacteria, transmitted through TB were Gram negative, while in study done by Maria Lincy et al (2016) showed majority of Gram negative bacteria from door handles.[13] In our study, majority of bacterial isolates were from toilets bowel, which may be due to improper working flush handle leading to insufficient flushing action and less frequency of cleaning the toilets resulting in poor sanitation. Second majority of bacterial contamination are flush handles due to poor sanitary conditions. Among Gram positive bacteria, Staphylococcus spp. showed highest resistance to Clindamycin (46\%) and less resistance to Chloramphenicol (6\%) antibiotics, followed by Streptococcus spp. shows higher resistance to Clindamycin (12\%) and
Cefoxitin and Gentamicin (10\%).Among Gram negative bacteria Citrobacter spp showed highest resistance to Erythromycin (23\%) and less resistance to Gentamicin (7\%) and Ciprofloxacin (8\%) antibiotics. (Table 3). In a similar study by Kimang'a et al (2012) shows, resistance of bacteria to Ampicillin, Amoxycillin, Chloramphenicol, Streptomycin, Spectinomycin, Cotrimoxazole, TMP-SMX, Kanamycin, Tetracycline and Gentamycin have been documented in different parts of Africa.[14] The antibiotic susceptibility patterns showed that all bacterial isolates were resistant to at least one antibiotic. The resistance of bacteria to commonly used antibiotics is an increasing problem worldwide and especially in developing countries.[15]

\section{CONCLUSION:}

Isolation of pathogenic bacteria from student's restrooms, may be due to the lack of water supply and improper cleaning of student's restroom. Present study highlights the need of sensitization \& training sessions regarding hand hygiene practices as well as assessment \& management about adequate sanitation practices, for all students who are staying in the hostels. Periodic cleaning of the student's restrooms with use of detergents or disinfectants in proper concentration should be done on regular basis. This is a prerequisite for reduction of carrying the contaminants from one surface to another, like from flush handle to door handle (inside as well as outside) of restroom.

\section{REFERENCES}

1. Hooper L V. (2001) Commensal Host-Bacterial Relationships in the Gut. Science (80-292:1115-1118)

2. Hooper DG, Shane J, et al (2010) Isolation of sulfur reducing, and oxidizing bacteria found in contaminated drywall. International Journal of Molecular Sciences 11:647-55.

3. Flores G, Bates S, Knights D (2011) Microbial biogeography of public restroom surfaces. PLoS One. doi: 10.1371/journal.pone.0028132

4. Adewoyin AG, Majolagbe ON, et al (2013) Antibiotic resistance profile of 
microbial isolates of toilet-bowl of some students' hostels in Ogbomoso, Nigeria. European Journal of Applied Sciences 5 (3): 76-79.

5. Kramer A., Schwebke I., Kampf G., How long do nosocomial pathogens persist on inanimate surfaces? A systematic review, BMC infectious diseases, 6,130 (2006)

6. Dancer S.J., White L.F., Lamb J et al, Measuring the effect of enhanced cleaning in a UK hospital: prospective cross-over study, BMC medicine, 7, 28 (2009)

7. Peleg AY, Hooper DC (2010) Hospital-acquired infections due to gramnegative bacteria. The New England Journal of Medicine 362:1804-13. doi: 10.1056/NEJMra0904124).

8. Watutantrige R.A., Premalatha $\mathrm{P}$ et al, A study on hand contamination and hand washing practices among medical students, ISRN Public Health, 5 (2012).

9. Scott E., Bloomfield S.F., Barlow C.G., An investigation of microbial contamination in the home, The Journal of hygiene, 89, 279-93 (1982) ]

10. Collee JG, Duguid JP, Fraser AG, Marmion BP, Simmons A. (Eds). Tests for the identification of bacteria. Mackie and Mc Cartney Practical Medical Microbiology. New Delhi, India: Elsevier publications; 2011:p131-149)

11. Toshima Y, Ojima M, Yamada H, Mori H, et al (2001) Observation of everyday handwashing behavior of Japanese, and effects of antibacterial soap. International Journal of Food Microbiology 68:83-91.

12. Agbagwa EO, Nwechem D (2010) Public health significance of microorganisms associated with public restrooms in University of port harcourt. Sci Africana 9:126-132

13. Maria Lincy ,Vidhya I, Arunadevi et al,Determination of bacterial and fungal loads and antibiotic susceptibility testing of bacteria isolated from public toilet door handles in Vellore district, Tamilnadu, India. International Journal of Research in Biosciences Vol. 5 Issue 4 pp. (69-78), October 2016

14. Kimang'a (2012) A situational analysis of antimicrobial drug resistance in Africa : are we losing the battle ? Ethiopian Journal of Health Sciences 22:135-140.

15. Giannini M.A., Nance D., McCullers J.A., Are toilet seats a vector for transmission of methicillin-resistant Staphylococcus aureus? American journal of infection control, 37, 505-6 (2009) 